\title{
Physiological performance of the cold-water coral Dendrophyllia cornigera reveals its preference for temperate environments
}

\author{
Andrea Gori · Stephanie Reynaud • \\ Covadonga Orejas · Josep-Maria Gili • \\ Christine Ferrier-Pagès
}

Received: 26 December 2013/ Accepted: 12 May 2014

(c) Springer-Verlag Berlin Heidelberg 2014

\begin{abstract}
Cold-water corals (CWCs) are key ecosystem engineers in deep-sea benthic communities around the world. Their distribution patterns are related to several abiotic and biotic factors, of which seawater temperature is arguably one of the most important due to its role in coral physiological processes. The CWC Dendrophyllia cornigera has the particular ability to thrive in several locations in which temperatures range from 11 to $17^{\circ} \mathrm{C}$, but to be apparently absent from most CWC reefs at temperatures constantly below $11^{\circ} \mathrm{C}$. This study thus aimed to assess the thermal tolerance of this CWC species, collected in the Mediterranean Sea at $12{ }^{\circ} \mathrm{C}$, and grown at the three relevant temperatures of 8,12 , and $16^{\circ} \mathrm{C}$. This species displayed thermal tolerance to the large range of seawater temperatures investigated, but growth, calcification, respiration, and total organic carbon (TOC) fluxes severely decreased at $8{ }^{\circ} \mathrm{C}$ compared to the in situ temperature of
\end{abstract}

Communicated by Biology Editor Dr. Anastazia Banaszak

Electronic supplementary material The online version of this article (doi:10.1007/s00338-014-1167-9) contains supplementary material, which is available to authorized users.

A. Gori $(\bowtie) \cdot$ S. Reynaud · C. Ferrier-Pagès

Centre Scientifique de Monaco (CSM), 8 Quai Antoine Ier, 98000 Monaco, Principality of Monaco

e-mail: agori.mail@gmail.com; agori@centrescientifique.mc

C. Orejas

Instituto Español de Oceanografía (IEO), Centro Oceanográfico de Baleares, Moll de Ponent s/n, 07015 Palma de Mallorca, Spain

J.-M. Gili

Institut de Ciències del Mar, Consejo Superior de Investigaciones Cientificas, Pg. Maritim de la Barceloneta 37-49, 08003 Barcelona, Spain
$12{ }^{\circ} \mathrm{C}$. Conversely, no significant differences in calcification, respiration, and TOC fluxes were observed between corals maintained at 12 and $16^{\circ} \mathrm{C}$, suggesting that the fitness of this CWC is higher in temperate rather than cold environments. The capacity to maintain physiological functions between 12 and $16^{\circ} \mathrm{C}$ allows $D$. cornigera to be the most abundant CWC species in deep-sea ecosystems where temperatures are too warm for other CWC species (e.g., Canary Islands). This study also shows that not all CWC species occurring in the Mediterranean Sea (at deepwater temperatures of $12-14{ }^{\circ} \mathrm{C}$ ) are currently living at their upper thermal tolerance limit.

Keywords Physiological ecology - Thermal tolerance . Coral calcification - Coral growth · Coral respiration . Organic carbon fluxes

\section{Introduction}

Cold-water corals (CWCs) are among the main engineering species (sensu Jones et al. 1994) in deep-sea ecosystems all over the world (Freiwald et al. 2004; Roberts et al. 2006, 2009a), where they play a crucial structural and functional role (Wildish and Kristmanson 1997; Gili and Coma 1998). From a structural point of view, many CWC species generate spatial heterogeneity by forming complex threedimensional reef frameworks that provide suitable habitat for hundreds of associated species (Krieger and Wing 2002; Roberts et al. 2009a; Buhl-Mortensen et al. 2010). The main environmental features, such as current flow, food availability, and sediment re-suspension, vary widely within these complex structures, and this heterogeneity increases the abundance and functional diversity of the associated fauna (Fosså et al. 2002; Henry and Roberts 
2007), particularly fish species (Baillon et al. 2012; Miller et al. 2012). From a functional point of view, CWCs determine a significant flow of matter and energy from the pelagic to the benthic system (Gili and Coma 1998; Van Oevelen et al. 2009), by capturing plankton and particulate organic matter suspended in the water (Duineveld et al. 2004, 2007, 2012; Carlier et al. 2009; Dodds et al. 2009). Dissolved and particulate organic mucoid compounds synthesized by CWCs and released into the water as an end product of catabolism can act as a vector for energy and a matter carrier in benthic-pelagic coupling, stimulating bacterioplankton growth and enhancing nutrient recycling via the microbial loop (Ferrier-Pages et al. 2000; Wild et al. 2004, 2008, 2009; Naumann et al. 2010).

The distribution of CWC species has been related to several abiotic and biotic factors such as seawater temperature and density, water flow regimes, aragonite saturation state, oxygen concentration, presence of suitable substrate, and food supply (Roberts et al. 2006; Davies et al. 2008; Dullo et al. 2008). Seawater temperature is considered one of the most important ecological factors driving CWC distribution (Freiwald et al. 2009; Roberts et al. 2009a) because it strongly controls coral physiological processes such as respiration (Buddemeier and Kinzie 1976; Coles and Jokiel 1977; Dodds et al. 2007; Naumann et al. 2014) and calcification (Clausen and Roth 1975; Howe and Marshall 2002; Naumann et al. 2014). Above or below their optimum thermal range, corals reduce their polyp activity (i.e., polyp expansion) and metabolism (Howe and Marshall 2001; Previati et al. 2010; FerrierPagès et al. 2012), before the appearance of lethal effects (Jokiel and Coles 1977; Coles and Fadlallah 1991; Rodolfo-Metalpa et al. 2006).

Among cold-water scleractinians, some species such as Lophelia pertusa, Madrepora oculata, Solenosmilia variabilis, and Desmophyllum dianthus show a widespread distribution throughout the world's oceans. Conversely, other CWC species like Dendrophyllia cornigera (Fig. 1) are restricted to particular geographical areas (Zibrowius 1980; Cairns 1994; Roberts et al. 2009a). The currently known distribution of $D$. cornigera (Fig. 2; Electronic Supplementary Material, ESM Table 1) includes the Mediterranean Sea at temperatures $\sim 12$ to $14{ }^{\circ} \mathrm{C}$ (Pérès and Picard 1964; Zibrowius 1980; Freiwald et al. 2009; Orejas et al. 2009; Salomidi et al. 2010; Bo et al. 2011; Gori et al. 2013), and the Eastern Atlantic from the south of Ireland to the Cape Verde Islands (Le Danois 1948; Zibrowius 1980; Álvarez-Claudio 1994; Brito and Ocaña 2004; Sánchez et al. 2009; Braga-Henriques et al. 2013), at temperatures ranging from 11 to $17^{\circ} \mathrm{C}$ (Le Danois 1948; Barton et al. 1998; Castaing et al. 1999; Valencia et al. 2004). In the Bay of Biscay, D. cornigera locally forms dense mono-specific aggregations between 50 and $620 \mathrm{~m}$

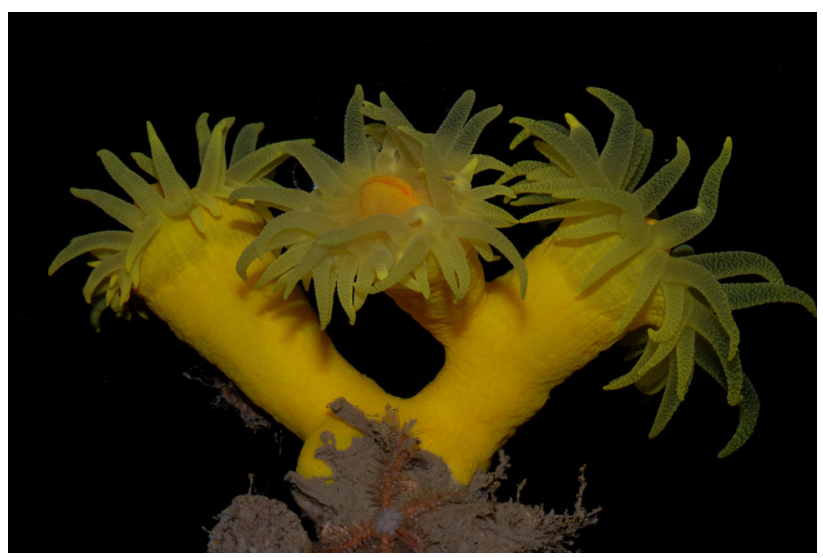

Fig. 1 The cold-water coral Dendrophyllia cornigera. Photo by PJ López-González

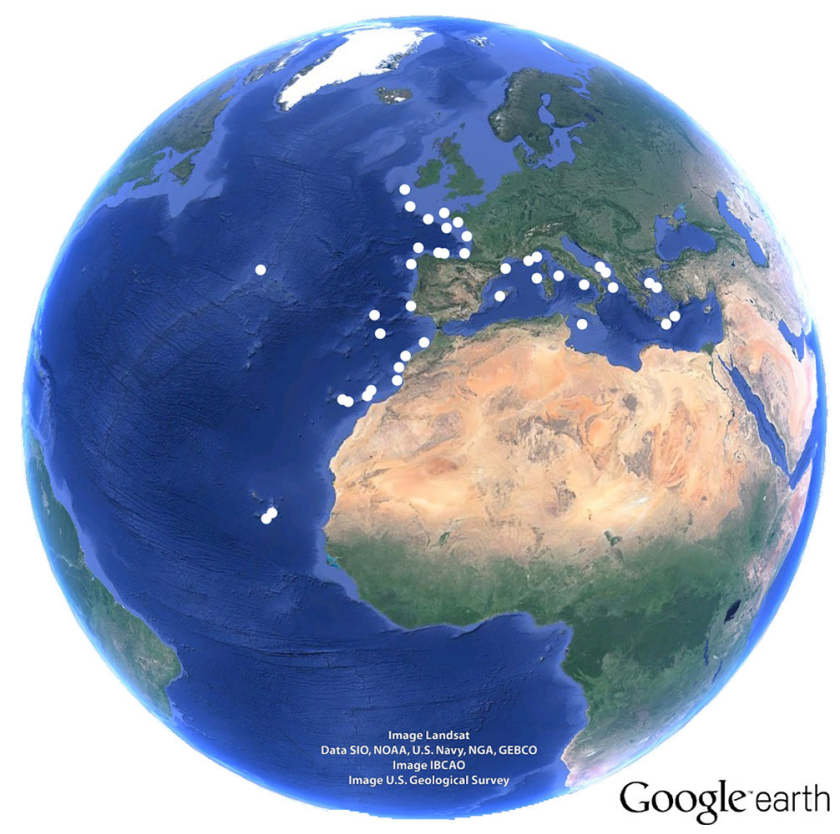

Fig. 2 Known distribution of Dendrophyllia cornigera based on a literature review of the confirmed identifications of live specimens (quoted in the text)

depth (Le Danois 1948; Álvarez-Claudio 1994; Reveillaud et al. 2008; Sánchez et al. 2009), and occurs at shallower depths of $30 \mathrm{~m}$ in areas characterized by upwelling of sea water at $11-14{ }^{\circ} \mathrm{C}$ (Castric-Fey 1996). Around the Canary Islands, D. cornigera is the dominant CWC species between 200 and $400 \mathrm{~m}$ depth (Brito and Ocaña 2004), at temperatures ranging from 13 to $16^{\circ} \mathrm{C}$ (Barton et al. 1998). However, D. cornigera is absent from the north-eastern Atlantic, where temperatures range from 5 to $10^{\circ} \mathrm{C}$ and reefs are dominated by $L$. pertusa (Dullo et al. 2008; Roberts et al. 2009b; Huvenne et al. 2011; Purser et al. 2013). All these observations suggest that, unlike other 
CWC species, the fitness of $D$. cornigera may be higher in temperate rather than cold environments.

To assess the potential effects of seawater temperature on the physiology of D. cornigera, rates of growth, calcification, respiration, and organic carbon (C) fluxes were measured at two temperatures $\left(12\right.$ and $\left.16{ }^{\circ} \mathrm{C}\right)$ near the extremes of its current thermal range, and at a lower temperature $\left(8^{\circ} \mathrm{C}\right)$ that is characteristic of the north-eastern Atlantic CWC reefs (Dullo et al. 2008; Roberts et al. 2009 b) where D. cornigera is absent. The aim of this study was to increase our knowledge on the thermal tolerance of D. cornigera, as temperature may be a key driver of its distribution.

\section{Materials and methods}

Coral collection and maintenance

Specimens of D. cornigera (Lamarck, 1816) (Fig. 1) were collected in the Menorca Channel (Balearic Archipelago, western Mediterranean Sea, $40^{\circ} 00^{\prime} 00^{\prime \prime} \mathrm{N}$; $003^{\circ} 32^{\prime} 20^{\prime \prime} \mathrm{E}$, at 180-330 m depth) by means of the manned submersible JAGO (IFM-GEOMAR, Kiel, Germany), and maintained alive on board the RV 'García del Cid' during the cruise INDEMARES 3 (April 2010). Corals were transported to the Institut de Ciències del Mar (CSIC; Barcelona, Spain) and maintained there in a $140-\mathrm{L}$ tank with a continuous flow of Mediterranean sea water pumped from $15 \mathrm{~m}$ depth at a rate of $60 \mathrm{~L} \mathrm{~h}^{-1}$ and filtered by a $50-\mu \mathrm{m}$ sand filter (Olariaga et al. 2009). Water temperature was maintained close to in situ conditions $\left(12 \pm 1.0^{\circ} \mathrm{C}\right)$, and two submersible pumps provided continuous water movement in the tank with a flow rate of $3,200 \mathrm{~L} \mathrm{~h}^{-1}$. Corals were fed five times a week with frozen Mysis (Crustacea, Eumalacostraca) and Artemia salina (Crustacea, Sarsostraca) adults. For the development of the experimental work, 15 specimens of $D$. cornigera were transferred to the Centre Scientifique de Monaco (CSM; Monaco, Principality of Monaco) and maintained during a month at the same temperature as in Barcelona $\left(12 \pm 1.0^{\circ} \mathrm{C}\right)$ in order to allow the specimens to acclimate. Corals were then placed into three different 25-L darkened tanks (five nubbins per tank) with a continuous flow of Mediterranean sea water freshly pumped from $50 \mathrm{~m}$ depth at a rate of $20 \mathrm{~L} \mathrm{~h}^{-1}$. Water temperature was maintained in each tank at $12 \pm 0.5^{\circ} \mathrm{C}$ by means of chillers (Teco TR 20, Ravenna, Italy) and 300-W heaters (Aquarium Systems Visi-therm, Sarrebourg, France) connected to independent temperature controllers (West 6100, Kassel, Germany). A submersible pump provided continuous water movement in each tank with a flow rate of $320 \mathrm{~L} \mathrm{~h}^{-1}$. Nubbins were distributed in order to have approximately the same skeletal mass and polyp number in each tank (Table 1) to ensure comparable magnitudes of growth and calcification rates. After one week under the above-controlled conditions, seawater temperature in two of the three tanks was changed stepwise $\left(0.5^{\circ} \mathrm{C} \mathrm{d}^{-1}\right)$ to reach the three experimental temperatures of $8 \pm 0.5,12 \pm 0.5$, and $16 \pm 0.5^{\circ} \mathrm{C}$. Corals were fed five times a week with a controlled daily supply of four Mysis per polyp and were maintained for $150 \mathrm{~d}$ under these conditions. Mysis were pipetted two to three times a day onto protruded polyps, and subsequent capture and ingestion were visually monitored to ensure food intake. To determine daily organic C supply, 12 Mysis were freezedried (Christ Alpha 2-4 LD, Osterode am Harz, Germany), acidified with $\mathrm{H}_{3} \mathrm{PO}_{4}\left(1 \mathrm{~mol} \mathrm{~L}{ }^{-1}, 100 \mu \mathrm{L}\right)$, and subsequently analysed using an elemental analyzer (Perkin Elmer, Waltham, MA, USA). Mean daily food-derived organic $\mathrm{C}$ input $\left(184 \pm 16 \mu \mathrm{mol} \mathrm{C}\right.$ polyp $\left.{ }^{-1} \mathrm{~d}^{-1}\right)$ was calculated using certified glycine standards (K-factor $32.0 \%$ C; Naumann et al. 2011).

Physiological measurements

After 10-d incubation at the right temperatures, the weight of each coral nubbin was assessed by means of the buoyant weight technique (Jokiel et al. 1978; Davies 1989) using an analytical balance (Mettler AT 261, L'Hospitalet de Llobregat, Spain, precision $0.1 \mathrm{mg}$ ). During the following

Table 1 Weight, surface, and number of polyps of the Dendrophyllia cornigera nubbins incubated under the three experimental temperatures

\begin{tabular}{|c|c|c|c|}
\hline $\begin{array}{l}\text { Treatment } \\
\left({ }^{\circ} \mathrm{C}\right)\end{array}$ & Weight (g) & $\begin{array}{l}\text { Surface } \\
\text { area }\left(\mathrm{cm}^{2}\right)\end{array}$ & $\begin{array}{l}\text { Number } \\
\text { of polyps }\end{array}$ \\
\hline \multirow[t]{6}{*}{8} & 15.8 & 34.4 & 2 \\
\hline & 12.4 & 31.9 & 1 \\
\hline & 9.4 & 23.7 & 2 \\
\hline & 6.6 & 19.0 & 2 \\
\hline & 2.1 & 8.7 & 1 \\
\hline & $9.3 \pm 5.3$ & $23.5 \pm 10.4$ & \\
\hline \multirow[t]{6}{*}{12} & 20.5 & 34.6 & 1 \\
\hline & 10.6 & 22.2 & 2 \\
\hline & 10.2 & 18.4 & 1 \\
\hline & 8.6 & 21.3 & 2 \\
\hline & 2.0 & 8.2 & 1 \\
\hline & $10.4 \pm 6.6$ & $20.9 \pm 9.4$ & \\
\hline \multirow[t]{6}{*}{16} & 15.3 & 28.2 & 2 \\
\hline & 15.0 & 32.3 & 2 \\
\hline & 9.8 & 32.4 & 2 \\
\hline & 6.2 & 18.2 & 1 \\
\hline & 3.3 & 12.9 & 1 \\
\hline & $9.9 \pm 5.3$ & $24.8 \pm 8.8$ & \\
\hline
\end{tabular}


$150 \mathrm{~d}$, the weight of each nubbin was measured eight times (approximately every $20 \mathrm{~d}$ ). Feeding was suspended $48 \mathrm{~h}$ before weight measurements to rule out excretion of undigested particulate food items. The bulk growth rate (i.e., skeletal + tissue) of each nubbin was calculated as the slope of the linear regression between the natural logarithm of the nubbin biomass $(\mathrm{mg})$ versus the experimental time (d). Bulk growth rates were expressed as percentages of daily weight increase $\left(\% \mathrm{~d}^{-1}\right)$ (Orejas et al. 2011a). The known percentage contribution of organic tissue biomass to bulk dry mass (14 $\pm 4 \%$; Movilla et al. 2014) allowed estimation of organic C flux into tissue growth (Naumann et al. 2011), assuming a comparable tissue ash-free dry weight organic $\mathrm{C}$ content, as previously reported for scleractinian corals and marine benthic macrofauna (41 and $40 \%$, respectively; Kang 1999; Schutter et al. 2010).

After $150 \mathrm{~d}$ under the three temperature conditions, three sets of incubations were performed to assess the rates of calcification, respiration, and organic $\mathrm{C}$ fluxes. Five nubbins per treatment were incubated for $6 \mathrm{~h}$ in individual beakers $(370 \mathrm{~mL})$, completely filled (without any air space) with $50 \mu \mathrm{m}$ pre-filtered sea water, hermetically closed with a plastic membrane impermeable to air, and maintained at the corresponding temperature in a water bath. One beaker, filled with pre-filtered sea water without any coral, was used as a control. Constant water movement inside the beakers was ensured by a Teflon-coated magnetic stirrer. The coral calcification rate was assessed by the total alkalinity (TA) anomaly technique (Smith and Key 1975; Langdon et al. 2010), assuming a consumption of two moles of alkalinity for every mole of calcium carbonate produced (Langdon et al. 2010). Seawater samples $(120 \mathrm{~mL})$ were drawn, before and after incubation, from each beaker, sterile-filtered $(0.2 \mu \mathrm{m})$, and kept refrigerated $\left(4{ }^{\circ} \mathrm{C}\right)$ pending analysis (performed within less than $48 \mathrm{~h}$ ). TA was determined on six subsamples of $20 \mathrm{~mL}$ from each beaker using a titration system composed of a $20-\mathrm{mL}$ open thermostated titration cell, a pH electrode calibrated on the National Bureau of Standards scale, and a computer-driven titrator (Metrohm 888 Titrando, Riverview, FL, USA). Seawater samples were kept at a constant temperature $\left(25.0 \pm 0.2^{\circ} \mathrm{C}\right)$ and weighed (Mettler AT 261, L'Hospitalet de Llobregat, Spain, precision $0.1 \mathrm{mg}$ ) before the titration to determine their exact volume from temperature and salinity. TA was calculated from the Gran function applied to $\mathrm{pH}$ variations from 4.2 to 3.0 as the function of added volume of $\mathrm{HCl}\left(0.1 \mathrm{~mol} \mathrm{~L}^{-1}\right)$, and TA values were corrected for changes in ammonium concentration (resulting from metabolic waste products) in experimental and control beakers (Jacques and Pilson 1980; Naumann et al. 2011). Samples for ammonium analysis $(20 \mathrm{~mL})$ were sterile-filtered $(0.2 \mu \mathrm{m})$ and kept frozen $\left(-20{ }^{\circ} \mathrm{C}\right)$ until ammonium concentration was determined in four replicates per sample by means of the spectrofluorometric method of Holmes et al. (1999). Variation in the TA measured from the control beaker was subtracted from those measured in the beakers with corals, and calcification rates were derived from the recorded depletion of TA over the 6-h incubation. Respiration rates were assessed by determining oxygen concentration in each beaker, at the beginning and end of the incubation, using an optode sensor (Hach-Lange HQ 40b, Loveland, CO, USA, precision $0.2 \mathrm{mg} \mathrm{L}^{-1}$ ). Variation in the oxygen concentration measured from the control beaker was subtracted from those measured in the coral beakers, and respiration rates were derived from the recorded depletion of dissolved oxygen over the incubation. Oxygen consumption rates were converted to $\mathrm{C}$ equivalents $(\mu \mathrm{mol})$ according to the equation $C$ respired $=\mathrm{O}_{2}$ consumed $\cdot R Q$, where $R Q$ is a coral-specific respiratory quotient equal to $0.8 \mathrm{~mol} \mathrm{C} \mathrm{mol}^{-1} \mathrm{O}_{2}$ (Anthony and Fabricius 2000; Ribes et al. 2003; Naumann et al. 2011). Organic C fluxes were assessed by calculating the difference in the seawater total organic carbon (TOC) concentration between the beginning and end of the incubation (Naumann et al. 2011). Seawater samples $(60 \mathrm{~mL})$ were drawn, before and after incubation, from each beaker, transferred into pre-combusted $\left(450{ }^{\circ} \mathrm{C}, 5 \mathrm{~h}\right)$ glass vials, acidified with phosphoric acid $(20 \%, 250 \mu \mathrm{L})$ to $\mathrm{pH}<2$, and kept frozen $\left(-20^{\circ} \mathrm{C}\right)$ until analysis by high-temperature catalytic oxidation (Shimadzu TOC-VCPH, Kyoto, Japan). Variation in the TOC measured from the control beaker was subtracted from those measured in the coral beakers, and TOC net fluxes were derived from the recorded variation of TOC over the 6-h incubation. Results from calcification, respiration, and organic $\mathrm{C}$ flux measurements were normalized to the coral skeletal surface area (fully covered by coral tissue), in order to allow for comparison with other coral species. The skeletal surface area $(S)$ of each coral nubbin was determined by means of advanced geometry (Naumann et al. 2009) according to the equation $S=\pi \cdot(r+R) \cdot a+\pi \cdot R^{2}$, where $r$ and $R$ represent the basal and apical radius of each polyp, respectively, and $a$ is the apothem measured with calipers (Rodolfo-Metalpa et al. 2006).

\section{Statistical analyses}

All results are expressed as mean \pm standard deviation. Normal distribution of the data was tested by means of Kolmogorov-Smirnov test performed with the R-language function ks.test of the R software platform (R Development Core Team 2012). Homogeneity of variances was tested by means of the Bartlett test performed with the R-language function bartlett.test. Differences among the three experimental temperatures in bulk growth rate, calcification, respiration, and organic $\mathrm{C}$ fluxes were tested by one-way 
ANOVA and subsequent post hoc analysis performed with the R-language function aov and tukeyHSD, respectively.

\section{Results}

Significant differences in bulk growth rate assessed by means of the buoyant weight technique (Fig. 3) were observed among the three temperatures (ANOVA, $F=21.69$, $p$ value $<0.001$; Table 2). Corals maintained at $8{ }^{\circ} \mathrm{C}$ grew significantly slower $\left(0.019 \pm 0.012 \% \mathrm{~d}^{-1}\right)$ than those maintained at $12{ }^{\circ} \mathrm{C}\left(0.061 \pm 0.020 \% \mathrm{~d}^{-1}\right)$, which also grew significantly slower than those maintained at $16{ }^{\circ} \mathrm{C}$ $\left(0.116 \pm 0.040 \% \mathrm{~d}^{-1}\right)$. Changes in TA in the incubation chambers (1.9-18.6 $\mu \mathrm{Eq} \mathrm{L} \mathrm{L}^{-1} \mathrm{~h}^{-1}$ ) were always distinguishable from changes measured in the control chambers $\left(<1.7 \mu \mathrm{Eq} \mathrm{L}{ }^{-1} \mathrm{~h}^{-1}\right)$, and calcification rates assessed by the TA anomaly technique (Fig. 4a) were significantly different among the experimental temperatures (ANOVA, $F=12.11, p$ value $=0.001 ;$ Table 2 ). Corals maintained at $8{ }^{\circ} \mathrm{C}$ calcified slower $\left(0.4 \pm 0.2 \mu \mathrm{mol} \mathrm{CaCO}_{3} \mathrm{~cm}^{-2} \mathrm{~d}^{-1}\right)$ than those maintained at $12{ }^{\circ} \mathrm{C}\left(1.5 \pm 0.6 \mu\right.$ mol $\mathrm{CaCO}_{3}-$ $\left.\mathrm{cm}^{-2} \mathrm{~d}^{-1}\right)$ or $16{ }^{\circ} \mathrm{C}\left(1.9 \pm 0.6 \mu \mathrm{mol} \mathrm{CaCO}_{3} \mathrm{~cm}^{-2} \mathrm{~d}^{-1}\right)$. Oxygen depletion attributable to coral respiration in the incubation chambers $\left(2.5-11.6 \mu \mathrm{mol} \mathrm{\textrm {L } ^ { - 1 }} \mathrm{h}^{-1}\right)$ was always higher than oxygen depletion in control chambers due to microbial respiration $\left(<1.2 \mu \mathrm{mol} \mathrm{L} \mathrm{L}^{-1} \mathrm{~h}^{-1}\right)$, and respiration rates (Fig. 4b) were significantly different among the tested temperatures (ANOVA, $F=10.47, \quad p$ value $=0.002$; Table 2). Corals maintained at $8{ }^{\circ} \mathrm{C}$ respired significantly less $\left(1.4 \pm 0.3 \mu \mathrm{mol} \mathrm{C} \mathrm{cm}^{-2} \mathrm{~d}^{-1}\right)$ than those maintained at

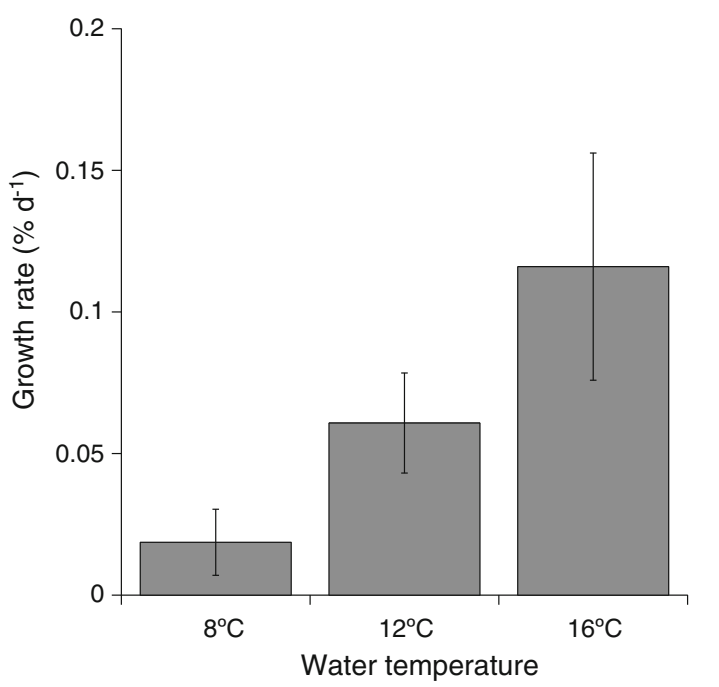

Fig. 3 Growth rate of Dendrophyllia cornigera under the three experimental temperatures, as a result of eight weight measurements carried out during $150 \mathrm{~d}$ (approximately every $20 \mathrm{~d}$ ). Values are presented as mean $\pm \mathrm{SD}$
Table 2 Pairwise test for comparison of the growth rate, calcification, respiration, and organic carbon fluxes, among the three experimental temperatures

\begin{tabular}{lccl}
\hline & $\begin{array}{l}8 / 12{ }^{\circ} \mathrm{C} \\
(p \text { value })\end{array}$ & $\begin{array}{l}8 / 16^{\circ} \mathrm{C} \\
(p \text { value })\end{array}$ & $\begin{array}{l}12 / 16^{\circ} \mathrm{C} \\
(p \text { value })\end{array}$ \\
\hline Growth & $0.037^{*}$ & $<0.001^{* * *}$ & $0.007 * *$ \\
Calcification & $<0.001^{* * *}$ & $0.001^{* *}$ & 0.505 \\
Respiration & $0.048^{*}$ & $0.002^{* *}$ & 0.192 \\
Organic carbon fluxes & $<0.001^{* * *}$ & $<0.001^{* * *}$ & 0.999 \\
\hline
\end{tabular}

$* p$ value $<0.05, * * p$ value $<0.01, * * * p$ value $<0.001$

$12{ }^{\circ} \mathrm{C} \quad\left(2.0 \pm 0.3 \mu \mathrm{mol} \mathrm{C} \mathrm{cm}^{-2} \mathrm{~d}^{-1}\right) \quad$ or $\quad 16{ }^{\circ} \mathrm{C}$ (2.4 $\pm 0.5 \mu \mathrm{mol} \mathrm{C} \mathrm{cm}{ }^{-2} \mathrm{~d}^{-1}$ ). TOC fluxes (Fig. 4c) were significantly different among the three temperatures treatments (ANOVA, $F=20.92, p$ value $<0.001$; Table 2 ), with a net uptake of TOC observed in corals maintained at $8{ }^{\circ} \mathrm{C}$ $\left(-0.56 \pm 0.15 \mu \mathrm{mol}\right.$ TOC $\left.\mathrm{cm}^{-2} \mathrm{~d}^{-1}\right)$, which contrasted with the substantial release of TOC observed in corals maintained both at $12^{\circ} \mathrm{C} \quad(0.88 \pm 0.34 \mu \mathrm{mol}$ TOC $\left.\mathrm{cm}^{-2} \mathrm{~d}^{-1}\right)$ and $16{ }^{\circ} \mathrm{C}\left(0.87 \pm 0.59 \mu \mathrm{mol}\right.$ TOC $\left.\mathrm{cm}^{-2} \mathrm{~d}^{-1}\right)$.

Concerning the $\mathrm{C}$ budget of $D$. cornigera at the three temperatures, feeding accounted for a mean organic $\mathrm{C}$ input of $184 \pm 16 \mu \mathrm{mol} \mathrm{C}$ polyp ${ }^{-1} \mathrm{~d}^{-1}$ corresponding to $13 \pm 4 \mu \mathrm{mol} \mathrm{C} \mathrm{cm}{ }^{-2} \mathrm{~d}^{-1}$. Respiration accounted for the main consumption of this organic $\mathrm{C}$ input and increased with temperature $\left(11,17\right.$, and $20 \%$ at 8,12 , and $16{ }^{\circ} \mathrm{C}$, respectively). Tissue growth also increased with temperature and accounted for 4,12 , and $16 \%$ at 8,12 , and $16{ }^{\circ} \mathrm{C}$, respectively. It has to be noticed that at $8{ }^{\circ} \mathrm{C}$, seawater TOC contributed to the input of organic $\mathrm{C}$, in addition to the particulate feeding ( $4 \%$ of the total organic $\mathrm{C}$ input), whereas at 12 and $16{ }^{\circ} \mathrm{C}$, the release of TOC (9 and $7 \%$ of the organic $\mathrm{C}$ input at 12 and $16{ }^{\circ} \mathrm{C}$, respectively) represented an additional loss of $\mathrm{C}$ from the coral.

\section{Discussion}

Dendrophyllia cornigera exhibited, in laboratory conditions, a pronounced tolerance to a wide thermal range (from 8 to $16{ }^{\circ} \mathrm{C}$ ). It has been previously demonstrated that lethal effects appear in corals at temperatures outside the species thermal range (Coles and Fadlallah 1991; Colella et al. 2012), with polyp contraction followed by massive loss of tissue (Jokiel and Coles 1977; Rodolfo-Metalpa et al. 2006). Such mortality was observed in L. pertusa when maintained for a week at $15{ }^{\circ} \mathrm{C}$ or at higher temperatures (Brooke et al. 2013). Conversely, no damage or coral mortality was observed in $D$. cornigera during our experiment (5 months) and until the present day (after 24 months), confirming that the upper thermal threshold of 

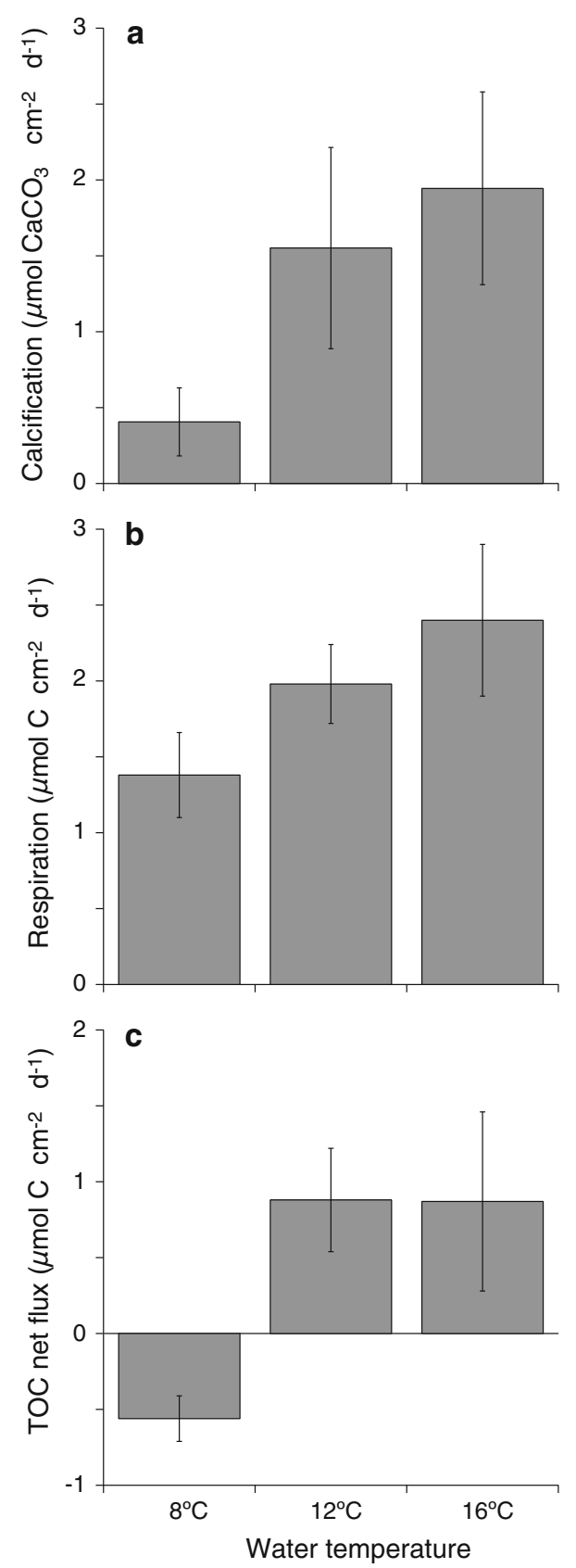

Fig. 4 Calcification rate (a), respiration rate (b), and total organic carbon (TOC) net flux (c) of Dendrophyllia cornigera under the three experimental temperatures, as the result of coral nubbins incubation in individual beakers for $6 \mathrm{~h}$. Values are presented as mean $\pm \mathrm{SD}$ normalised to coral skeletal surface area

some CWC species may be higher than previously assumed (Naumann et al. 2013).

Dendrophyllia cornigera demonstrated no thermal acclimation to low temperatures, suggesting that the fitness of this CWC is higher in temperate rather than cold-water environments. Indeed, its metabolism was severely decreased at $8{ }^{\circ} \mathrm{C}$ compared to the in situ temperature of $12{ }^{\circ} \mathrm{C}$, with a significant reduction in growth rate by
$300 \%$, calcification rate by $70 \%$, and respiration rate by $30 \%$. The observed shift from release to uptake of TOC at $8{ }^{\circ} \mathrm{C}$ also supports this substantial reduction in coral metabolism at this low temperature, since organic matter release by corals in ambient sea water depends on their metabolic activity (Ferrier-Pagès et al. 1998; Wild et al. 2008; Naumann et al. 2011). Such a reduction in metabolism was previously observed in tropical coral species when seawater temperature fell below their natural thermal range (Coles and Fadlallah 1991; Kemp et al. 2011). Calcification rates of tropical (e.g., Jokiel and Coles 1977; Coles and Jokiel 1978; Lough and Barnes 2000; Abramovitch-Gottlib et al. 2002) and temperate corals (e.g., Jacques et al. 1983; Howe and Marshall 2002; RodolfoMetalpa et al. 2008a) are strongly influenced by temperature, and a growth response to temperature has been previously observed also in the CWC Oculina varicosa (Reed 1981). Low growth rates could be directly induced by the effect of temperature on the activity of the enzymes involved in calcification (such as the carbonic anhydrases; Ip et al. 1991; Al-Horani et al. 2003; Allemand et al. 2004), since enzyme activity is maximal within the thermal range of the organism and decreases otherwise (Jacques et al. 1983; Marshall and Clode 2004; Al-Horani 2005). Moreover, a possible reduced digestion and/or assimilation efficiency at low temperature (Glynn and Stewart 1973) could also have resulted in a lower organic $\mathrm{C}$ availability for corals maintained at $8{ }^{\circ} \mathrm{C}$, even if the amount of ingested organic $\mathrm{C}$ was the same for all corals (see Materials and Methods). This is also suggested by the observed decrease in the amount of $\mathrm{C}$ employed for tissue growth, respiration, and organic $\mathrm{C}$ fluxes at $8{ }^{\circ} \mathrm{C}(\sim 19 \%$ of the ingested organic $\mathrm{C})$, compared to $12{ }^{\circ} \mathrm{C}(\sim 38 \%)$ and $16{ }^{\circ} \mathrm{C}(\sim 43 \%)$. No significant differences in the rates of calcification, respiration, and TOC release were observed between corals maintained at 12 and $16{ }^{\circ} \mathrm{C}$, suggesting that D. cornigera can tightly control its metabolic activity within its natural thermal range (Sassaman and Mangum 1970; Jacques et al. 1983; Howe and Marshall 2001). Such a thermal acclimation was previously observed in $L$. pertusa colonies from the Mediterranean Sea, which kept respiration rates constant between 6 and $12{ }^{\circ} \mathrm{C}$, and calcification rates constant between 9 and $12{ }^{\circ} \mathrm{C}$ (Naumann et al. 2014), as well as in the temperate coral Leptosammia pruvoti, whose calcification rate was not correlated with seawater temperature (Caroselli et al. 2012). Although the calcification rate assessed by the TA anomaly technique was not significantly different between 12 and $16{ }^{\circ} \mathrm{C}$, the enhanced growth rates at $16{ }^{\circ} \mathrm{C}$ shown by the buoyant weight measures is in agreement with the observed higher tissue growth at $16{ }^{\circ} \mathrm{C}$ and highlights that $D$. cornigera metabolism is more efficient at the higher temperature within its thermal range. 
Growth, calcification, and respiration rates of $D$. cornigera at the in situ Mediterranean temperature of $12{ }^{\circ} \mathrm{C}$ are consistent with previous data obtained from the same species (Orejas et al. 2011a; Naumann et al. 2013) and are in the same order of magnitude as those reported for other Mediterranean CWCs L. pertusa, M. oculata (e.g., Maier et al. 2009, 2012; Orejas et al. 2011a, 2011b; Naumann et al. 2014), and D. dianthus (Naumann et al. 2011, 2013). Overall, Mediterranean CWCs have a reduced metabolic activity (Naumann et al. 2011) and lower calcification rates compared to most tropical corals (13.9-194.0 $\mu \mathrm{mol} \mathrm{CaCO}_{3} \mathrm{~cm}^{-2} \mathrm{~d}^{-1}$; Lough and Barnes 2000; Carricart-Garnivet 2004; Colombo-Pallotta et al. 2010), but have comparable rates to most temperate coral species (1.5-3.12 $\mu \mathrm{mol} \mathrm{CaCO}_{3} \mathrm{~cm}^{-2} \mathrm{~d}^{-1}$; Kevin and Hudson 1979; Jacques et al. 1983; Howe and Marshall 2002; Rodolfo-Metalpa et al. 2008b). Organic C release at the in situ temperature of $12{ }^{\circ} \mathrm{C}$ was higher in Dendrophyllia cornigera $\left(0.88 \pm 0.34 \mu \mathrm{mol} \mathrm{C} \mathrm{cm}{ }^{-2} \mathrm{~d}^{-1}\right)$ than in Desmophyllum dianthus ( $\sim 0.4 \mu$ mol $\mathrm{C} \mathrm{cm}^{-2} \mathrm{~d}^{-1}$, Naumann et al. 2011), which highlights its functional role as a source of particulate and/or dissolved organic matter that can stimulate bacterioplankton growth and enhance nutrient recycling via the microbial loop (Ferrier-Pagès et al. 1998; Wild et al. 2008, 2009). However, both species release much less organic matter than L. pertusa $\left(\sim 9.6 \mu \mathrm{mol} \mathrm{C} \mathrm{cm}{ }^{-2} \mathrm{~d}^{-1}\right.$; Wild et al. 2008). The bulk of organic matter released by corals mainly originates from coral mucus (Crossland 1987; Wild et al. 2004; Naumann et al. 2010), which may play an important role in the entanglement and capture of small food particles (Lewis and Price 1975). This may suggest a possible low importance of mucus production in the trophic strategy of Dendrophyllia cornigera and Desmophyllum dianthus, possibly due to a preference of these species for large prey captured by means of tentacle activity (Lewis and Price 1975) of their large polyps.

The severe reduction observed in the rates of the main physiological processes at $8{ }^{\circ} \mathrm{C}$ may explain why $D$. cornigera is currently absent from areas dominated by other CWC species and characterized by temperatures constantly below $12{ }^{\circ} \mathrm{C}$ (e.g., Norwegian reefs, Tisler reef, Mingulay reef; Dullo et al. 2008; Roberts et al. 2009b; Huvenne et al. 2011). However, its capacity to maintain efficient physiological function between 12 and $16{ }^{\circ} \mathrm{C}$ enables $D$. cornigera to be the most abundant $\mathrm{CWC}$ species in deep-sea ecosystems where temperature conditions are currently not suitable for the otherwise more widespread CWCs L. pertusa and M. oculata (e.g., Canary Islands; Brito and Ocaña 2004). The thermal tolerance of $D$. cornigera also highlights that not all CWC species dwelling on the continental shelf and slope of the Mediterranean Sea (at temperatures of $12-14{ }^{\circ} \mathrm{C}$ ) are currently living at their upper thermal limit (Freiwald et al. 2009; Brooke et al. 2013). Large-scale warming of the Mediterranean Sea
(Walther et al. 2002) and its deep waters $\left(\sim 0.12{ }^{\circ} \mathrm{C}\right.$ in $30 \mathrm{yr}$ in the Western basin; Bethoux et al. 1990) may therefore contribute to a future shift in the Mediterranean CWC community composition, with a potential reduction in L. pertusa abundance (whose upper limit of thermal tolerance is near $15^{\circ} \mathrm{C}$; Brooke et al. 2013), and an increase in D. cornigera abundance.

Acknowledgments The authors are indebted to the crew and scientists on board the RV 'García del Cid', as well as to the JAGO team, J. Schauer and K. Hissmann (IFM-GEOMAR, Kiel, Germany) for their help during the coral collection. We are grateful to A. Olariaga, C. Domínguez-Carrió, J. Grinyó, and S. Ambroso for helping with the coral care in Barcelona, to the personnel from the Musée Océanographique de Monaco for helping with the coral care in Monaco, to P.J. López-González for the picture in Fig. 1, A. BragaHenriques, A. Brito and M. Bo for information about D. cornigera occurrence and seawater temperature, to S. Sikorski and C. Rottier for laboratory assistance, to A. Venn and S. Hennige for revision of the English, and to D. Allemand for discussions. This work was supported by the Government of the Principality of Monaco, and by the European Project LIFE + INDEMARES 'Inventario y designación de la red natura 2000 en áreas marinas del estado español' (LIFE07/NAT/ E/000732), and HERMIONE (Grant Agreement Number 226354).

\section{References}

Abramovitch-Gottlib L, Katoshevski D, Vago R (2002) A computerized tank system for studying the effect of temperature on calcification of reef organisms. J Biochem Biophys Methods $50: 245-252$

Al-Horani FA (2005) Effects of changing seawater temperature on photosynthesis and calcification in the scleractinian coral Galaxea fascicularis, measured with $\mathrm{O}_{2}, \mathrm{Ca}^{2+}$ and $\mathrm{pH}$ microsensors. Sci Mar 69:347-354

Al-Horani FA, Al-Moghrabi SM, De Beer D (2003) The mechanism of calcification and its relation to photosynthesis and respiration in the scleractinian coral Galaxea fascicularis. Mar Biol 142:419-426

Allemand D, Ferrier-Pagès C, Furla $\mathrm{P}$, Houlbrèque F, Puverel S, Reynaud S, Tambutté E, Tambutté S, Zoccola D (2004) Biomineralisation in reef-building corals: from molecular mechanisms to environmental control. C R Palevol 3:453-467

Álvarez-Claudio C (1994) Deep-water Scleractinia (Cnidaria Anthozoa) from southern Biscay Bay. Cah Biol Mar 35:461-469

Anthony KRN, Fabricius KE (2000) Shifting roles of heterotrophy and autotrophy in coral energy budgets at variable turbidity. J Exp Mar Biol Ecol 252:221-253

Baillon S, Hamel JF, Wareham VE, Mercier A (2012) Deep coldwater corals as nurseries for fish larvae. Front Ecol Environ $10: 351-356$

Barton ED, Arístegui J, Tett P, Cantón M, García-Braun J, Hernández-León S, Nykjaer L, Almeida C, Almunia J, Ballesteros S, Basterretxea G, Escánez J, García-Weill L, HernándezGuerra A, López-Laatzen F, Molina R, Montero MF, NavarroPérez E, Rodríguez JM, van Lenning K, Vélez H, Wild K (1998) The transition zone of the Canary Current upwelling region. Prog Oceanogr 41:450-455

Bethoux JP, Gentili B, Raunet J, Tailliez D (1990) Warming trend in the western Mediterranean deep water. Nature 347:660-662

Bo M, Bertolino B, Borghini M, Castellano M, Harriague AC, Di Camillo CG, Gasparini G, Misic C, Povero P, Pusceddu A, 
Schroeder K, Bavestrello G (2011) Characteristics of the mesophotic megabenthic assemblages of the Vercelli Seamount (North Tyrrhenian Sea). PLoS One 6:e16357

Braga-Henriques A, Porteiro FM, Ribeiro PA, de Matos V, Sampaio Í, Ocaña O, Santos RS (2013) Diversity, distribution and spatial structure of the cold-water coral fauna of the Azores (NE Atlantic). Biogeosciences 10:4009-4036

Brito A, Ocaña O (2004) Corales de las islas Canarias. Antozoos con esqueleto de los fondos litorales y profundos. Francisco Lemus Editor, La Laguna

Brooke S, Ross SW, Bane JM, Seim HE, Young CM (2013) Temperature tolerance of the deep-sea coral Lophelia pertusa from the southeastern United States. Deep Sea Res Pt 2 Top Stud Oceanogr 92:240-248

Buddemeier RW, Kinzie RA (1976) Coral growth. Oceanogr Mar Biol Annu Rev 14:183-225

Buhl-Mortensen LA, Vanreusel AJ, Gooday LA, Levin I, Priede G, Buhl-Mortensen P, Gheerardyn H, King NJ, Raes M (2010) Biological structures as a source of habitat heterogeneity and biodiversity on the deep ocean margins. Mar Ecol 31:21-50

Cairns SD (1994) Scleractinia of the temperate north Pacific. Smithsonian Institution Press, Washington, DC, pp 1-150

Carlier A, Le Guilloux E, Olu K, Sarrazin J, Mastrototaro F, Taviani M, Clavier J (2009) Trophic relationships in a deep Mediterranean cold-water coral bank (Santa Maria di Leuca, Ionian Sea). Mar Ecol Prog Ser 397:125-137

Caroselli E, Zaccanti F, Mattioli G, Falini G, Levy O, Dubinsky Z, Goffredo S (2012) Growth and demography of the solitary scleractinian coral Leptopsammia pruvoti along a sea surface temperature gradient in the Mediterranean Sea. PLoS One 76:e37848

Carricart-Garnivet JP (2004) Sea surface temperature and the growth of the West Atlantic reef building coral Montastrea annularis. J Exp Mar Biol Ecol 302:249-260

Castaing P, Froidefond JM, Lazure P, Weber O, Prud'homme R, Jouanneau JM (1999) Relationship between hydrology and seasonal distribution of suspended sediments on the continental shelf of the Bay of Biscay. Deep-Sea Res Part 2 Top Stud Oceanogr 46:1979-2001

Castric-Fey A (1996) Le Scléractiniaire Dendrophyllia cornigera en eau peu profonde, à Ouessant (Bretagna, Atlantique NE) en l'absence de barrière thermique. Oceanologica Acta 19:665-671

Clausen CD, Roth AA (1975) Effect of temperature and temperature adaptation on calcification rate in the hermatypic coral Pocillopora damicornis. Mar Biol 33:93-100

Colella MA, Ruzucka RR, Kidney JA, Morrison JM, Brinkhuis VB (2012) Cold-water event of January 2010 results in catastrophic benthic mortality on patch reefs in the Florida Keys. Coral Reefs 31:621-632

Coles SL, Jokiel PL (1977) Effects of temperature on photosynthesis and respiration in hermatypic corals. Mar Biol 43:209-216

Coles SL, Jokiel PL (1978) Synergistic effects of temperature, salinity and light on the hermatypic coral Montipora verrucosa. Mar Biol 49:187-195

Coles SL, Fadlallah YH (1991) Reef coral survival and mortality at low temperatures in the Arabian Gulf: new species-specific lower temperature limits. Coral Reefs 9:231-237

Colombo-Pallotta MF, Rodriguez-Roman A, Iglesias-Prieto R (2010) Calcification in bleached and unbleached Montastraea faveolata: evaluating the role of oxygen and glycerol. Coral Reefs 29:899-907

Crossland C (1987) In situ release of mucus and DOC-lipid from the corals Acropora variabilis and Stylophora pistillata in different light regimes. Coral Reefs 6:35-42

Davies PS (1989) Short-term growth measurements of corals using an accurate buoyant weighing technique. Mar Biol 101:389-395
Davies AJ, Wisshak MO, James C, Roberts JM (2008) Predicting suitable habitat for the cold-water coral Lophelia pertusa (Scleractinia). Deep Sea Res Pt 1 Oceanogr Res Pap 55:1048-1062

Dodds LA, Roberts JM, Taylor AC, Marubini F (2007) Metabolic tolerance of the cold-water coral Lophelia pertusa (Scleractinia) to temperature and dissolved oxygen change. J Exp Mar Biol Ecol 349:205-214

Dodds LA, Black KD, Orr H, Roberts JM (2009) Lipid biomarkers reveal geographical differences in food supply to the cold-water coral Lophelia pertusa (Scleractinia). Mar Ecol Prog Ser 397:113-124

Duineveld G, Lavaleye M, Berghuis E (2004) Particle flux and food supply to a seamount cold-water coral community (Galicia Bank, NW Spain). Mar Ecol Prog Ser 277:13-23

Duineveld G, Lavaleye M, Bergman M, De Stigter H, Mienis F (2007) Trophic structure of a cold-water coral mound community (Rockall Bank, NE Atlantic) in relation to the near-bottom particle supply and current regime. Bull Mar Sci 81:449-467

Duineveld GCA, Jeffreys RM, Lavaleye MSS, Davies AJ, Bergman MJN, Watmough T, Witbaard R (2012) Spatial and tidal variation in food supply to shallow cold-water coral reefs of the Mingulay Reef complex (Outer Hebrides, Scotland). Mar Ecol Prog Ser 444:97-115

Dullo WC, Flögel S, Rüggeberg A (2008) Cold-water coral growth in relation to the hydrography of the Celtic and Nordic European continental margin. Mar Ecol Prog Ser 371:165-176

Ferrier-Pagès C, Reynaud S, Allemand D (2012) Shallow water Scleractinian corals of the Mediterranean Sea. In: Stambler N (ed) Life in the Mediterranean Sea: a look at habitat changes. Nova Science Publishers Inc., New York

Ferrier-Pages C, Leclercq N, Jaubert J, Pelegri SP (2000) Enhancement of pico- and nanoplankton growth by coral exudates. Aquat Microb Ecol 21:203-209

Ferrier-Pagès C, Gattuso JP, Cauwet G, Jaubert J, Allemand D (1998) Release of dissolved organic carbon and nitrogen by the zooxanthellate coral Galaxea fascicularis. Mar Ecol Prog Ser 172:265-274

Fosså JH, Mortensen PB, Furevik DM (2002) The deepwater coral Lophelia pertusa in Norwegian waters: distribution and fishery impacts. Hydrobiologia 471:1-12

Freiwald A, Fossa JH, Grehan A, Koslow T, Roberts JM (2004) Coldwater coral reefs-out of sight no longer our of mind. Biodiversity Series 22. UNEP-WCMC, Cambridge, UK

Freiwald A, Beuck L, Rüggeberg A, Taviani M, Hebbeln D (2009) The white coral community in the Central Mediterranean Sea revealed by ROV surveys. Oceanography 22:58-74

Gili JM, Coma R (1998) Benthic suspension feeders: their paramount role in littoral marine food webs. Tree 13:316-321

Glynn PW, Stewart RH (1973) Distribution of coral reefs in the Pearl Islands (Gulf of Panama) in relation to thermal conditions. Limnol Oceanogr 18:367-379

Gori A, Orejas C, Madurell T, Bramanti L, Martins M, Quintanilla E, Marti-Puig P, Lo Iacono C, Puig P, Requena S, Greenacre M, Gili JM (2013) Bathymetrical distribution and size structure of cold-water coral populations in the Cap de Creus and LacazeDuthiers canyons (northwestern Mediterranean). Biogeosciences 10:2049-2060

Henry LA, Roberts JM (2007) Biodiversity and ecological composition of macrobenthos on cold-water coral mounds and adjacent off-mound habitat in the bathyal Porcupine Seabight, NE Atlantic. Deep Sea Res Part 1 Oceanogr Res Pap 54:654-672

Holmes RM, Aminot A, Kérouel R, Hooker BA, Peterson BJ (1999) A simple and precise method for measuring ammonium in marine and freshwater ecosystems. Can J Fish Aquat Sci 56:1801-1808

Howe SA, Marshall AT (2001) Thermal compensation of metabolism in the temperate coral Plesiastrea versipora (Lamark 1816). J Exp Mar Biol Ecol 259:231-248 
Howe SA, Marshall AT (2002) Temperature effects on calcification rate and skeletal deposition in the temperate coral Plesiastrea versipora (Lamarck). J Exp Mar Biol Ecol 275:63-81

Huvenne VAI, Tyler PA, Masson DG, Fisher EH, Hauton C, Hühnerbach V, Le Bas TP, Wolff GA (2011) A picture on the wall: innovative mapping reveals cold-water coral refuge in submarine canyon. PLoS One 6:e28755

Ip YK, Lim LL, Lim RWL (1991) Some properties of calciumactivated adenosine triphosphate from the hermatypic coral Galaxea fascicularis. Mar Biol 111:191-197

Jacques TG, Pilson MEQ (1980) Experimental Ecology of the temperate scleractinian coral Astrangia danae I. Partition of respiration, photosynthesis and calcification between host and symbionts. Mar Biol 60:167-178

Jacques TG, Marshall N, Pilson MEQ (1983) Experimental ecology of the temperate scleractinian coral Astrangia danae. II Effect of temperature, light intensity and symbiosis with zooxanthellae on metabolic rate and calcification. Mar Biol 76:135-148

Jokiel PL, Coles SL (1977) Effects of temperature on the mortality and growth of Hawaiian reef corals. Mar Biol 43:201-208

Jokiel PL, Maragos JE, Franzisket L (1978) Coral growth: buoyant weight technique. In: Stoddard JR, Johannes RE (eds) Coral reefs: research methods. UNESCO, Paris

Jones CG, Lawton JH, Shachak M (1994) Organisms as ecosystem engineers. Oikos 69:373-386

Kang CK (1999) Structures trophiques et production secondaire dans les réseaux benthiques intertidaux du bassin de MarennesOléron: utilisation du traçage isotopique naturel. Ph.D. thesis, University of Nantes, Nantes, France

Kemp DW, Oakley CA, Thornhill DJ, Newcomb LA, Schmidt GW, Fitt WK (2011) Catastrophic mortality on inshore coral reefs of the Florida Keys due to severe low-temperature stress. Glob Change Biol 17:3468-3477

Kevin KM, Hudson RCL (1979) The role of zooxanthellae in the hermatypic coral Plesiastrea urvillei (Milne Edwards and Haime) from cold waters. J Exp Mar Biol Ecol 36:157-170

Krieger KJ, Wing B (2002) Megafauna associations with deepwater corals (Primnoa sp.) in the Gulf of Alaska. Hydrobiologia 471:83-90

Langdon C, Gattuso JP, Andersson A (2010) Measurement of calcification and dissolution of benthic organisms and communities. In: Riebesell U, Fabry VJ, Hanson L, Gattuso JP (eds) Guide to best practices for ocean acidification research and data reporting. Publications office of the European Union, Luxembourg

Le Danois E (1948) Les profondeurs de la mer. Payot, Paris

Lewis JB, Price WS (1975) Feeding mechanisms and feeding strategies of Atlantic reef corals. J Zool Lond 176:527-544

Lough JM, Barnes DJ (2000) Environmental controls on growth of the massive coral Porites. J Exp Mar Biol Ecol 245:225-243

Maier C, Hegeman J, Weinbauer MG, Gattuso JP (2009) Calcification of the cold-water coral Lophelia pertusa under ambient and reduced $\mathrm{pH}$. Biogeosciences 6:1875-1901

Maier C, Watremez P, Taviani M, Weinbauer MG, Gattuso JP (2012) Calcification rates and the effect of ocean acidification on Mediterranean cold-water corals. Proc R Soc Lond B Biol Sci 279:1716-1723

Marshall AT, Clode P (2004) Calcification rate and the effect of temperature in a zooxanthellate and an azooxanthellate scleractinian reef coral. Coral Reefs 23:218-224

Miller RJ, Hocevar J, Stone RP, Fedorov DV (2012) Structureforming corals and sponges and their use as fish habitat in Bering Sea submarine canyons. PLoS One 7:e33885

Movilla J, Orejas C, Calvo E, Gori A, López-Sanz À, Grinyó J, Domínguez-Carrió C, Pelejero C (2014) Differential response of two Mediterranean cold-water coral species to ocean acidification. Coral Reefs. doi:10.1007/s00338-014-1159-9
Naumann MS, Orejas C, Ferrier-Pagès C (2013) High thermal tolerance of two Mediterranean cold-water coral species maintained in aquaria. Coral Reefs 32:749-754

Naumann MS, Orejas C, Ferrier-Pagès C (2014) Species-specific physiological response by the cold-water corals Lophelia pertusa and Madrepora oculata to variations within their natural temperature range. Deep Sea Res Part 2 Top Stud Oceanogr 99:36-41

Naumann MS, Orejas C, Wild C, Ferrier-Pagès C (2011) First evidence for zooplankton feeding sustaining key physiological processes in a scleractinian cold-water coral. J Exp Biol 214:3570-3576

Naumann MS, Niggl W, Laforsch C, Glaser C, Wild C (2009) Coral surface area quantification - evaluation of established methods by comparison with computer tomography. Coral Reefs 28:109-117

Naumann MS, Haas A, Struck U, Mayr C, el-Zibdah M, Wild C (2010) Organic matter release by dominant hermatypic corals of the Northern Red Sea. Coral Reefs 29:649-659

Olariaga A, Gori A, Orejas C, Gili JM (2009) Development of an autonomous aquarium system for maintaining deep corals. Oceanography 22:44-45

Orejas C, Gori A, Lo Iacono C, Puig P, Gili JM (2009) Cold-water corals in the Cap de Creus canyon, northwestern Mediterranean: spatial distribution, density and anthropogenic impact. Mar Ecol Prog Ser 397:37-51

Orejas C, Ferrier-Pagès C, Reynaud S, Gori A, Beraud E, Tsounis G, Allemand D, Gili JM (2011a) Long-term growth rate measurements of four Mediterranean cold water coral species (Madrepora oculata, Lophelia pertusa, Desmophyllum cristagalli and Dendrophyllia cornigera) maintained in aquaria. Mar Ecol Prog Ser 429:57-65

Orejas C, Ferrier-Pagès C, Reynaud S, Tsounis G, Allemand D, Gili JM (2011b) Experimental comparison of skeletal growth rates in the cold-water coral Madrepora oculata Linnaeus, 1758 and three tropical scleractinian corals. J Exp Mar Biol Ecol 405:1-5

Pérès JM, Picard J (1964) Nouveau manuel de bionomie benthique de la mer Mediterranée. Station Marine d'Endoume 31:5-137

Previati M, Scinto A, Cerrano C, Osinga R (2010) Oxygen consumption in Mediterranean octocorals under different temperatures. J Exp Mar Biol Ecol 390:39-48

Purser A, Orejas C, Gori A, Tong T, Unnithan V, Thomsen L (2013) Local variation in the distribution of benthic megafauna species associated with cold-water coral reefs on the Norwegian margin. Cont Shelf Res 54:37-51

R Core Development Team (2012) R: A language and environment for statistical computing. R Foundation for Statistical Computing, Vienna, Austria. ISBN 3-900051- 07-0, URL. http://www.Rproject.org

Reed JK (1981) In situ growth rates of the scleractinian coral Oculina varicosa occurring with zooxanthellae on $6 \mathrm{~m}$ reefs and without on 80 m banks. Proc 4th Int Coral Reef Symp 2:201-206

Reveillaud J, Freiwald A, Van Rooij D, Le Guilloux E, Altuna A, Foubert A, Vanreusel A, Olu-Le Roy K, Henriet JP (2008) The distribution of scleractinian corals in the Bay of Biscay, NE Atlantic. Facies 54:317-331

Ribes M, Coma R, Rossi S (2003) Natural feeding of the temperate asymbiotic octocoral-gorgonian Leptogorgia sarmentosa (Cnidaria: Octocorallia). Mar Ecol Prog Ser 254:141-150

Roberts JM, Wheeler AJ, Freiwald A (2006) Reefs of the deep: the biology and geology of cold-water coral ecosystems. Science 312:543-547

Roberts JM, Wheeler AJ, Freiwald A, Cairns S (2009a) Cold-water corals: the biology and geology of deep-sea coral habitats. Cambridge University Press, Cambridge

Roberts JM, Davies AJ, Henry LA, Dodds LA, Duineveld GCA, Lavaleye MSS, Maier C, van Soest RWM, Bergman MJN, Hühnerbach V, Huvenne VAI, Sinclair DJ, Watmough T, Long 
D, Green SL, van Haren H (2009b) Mingulay reef complex: an interdisciplinary study of cold-water coral habitat, hydrography and biodiversity. Mar Ecol Prog Ser 397:139-151

Rodolfo-Metalpa R, Richard C, Allemand D, Ferrier-Pagès C (2006) Growth and photosynthesis of two Mediterranean corals, Cladocora caespitosa and Oculina patagonica, under normal and elevated temperatures. J Exp Biol 209:4546-4556

Rodolfo-Metalpa R, Reynaud S, Allemand D, Ferrier-Pagès C (2008a) Temporal and depth response of two temperate corals, Cladocora caespitosa and Oculina patagonica from the north Mediterranean Sea. Mar Ecol Prog Ser 369:103-114

Rodolfo-Metalpa R, Peirano A, Houlbrèque F, Abbate M, FerrierPagès C (2008b) Effects of temperature, light and heterotrophy on the growth of the temperate coral Cladocora caespitosa. Coral Reefs 27:17-25

Salomidi M, Zibrowius H, Issaris Y, Milionis K (2010) Dendrophyllia in Greek waters, Mediterranean Sea, with first record of D. ramea (Cnidaria, Scleractinia) from the area. Mediterr Mar Sci 11:189-194

Sánchez F, Serrano A, Ballesteros MG (2009) Photogrammetric quantitative study of habitat and benthic communities of deep Cantabrian Sea hard grounds. Cont Shelf Res 29:1174-1188

Sassaman C, Mangum CP (1970) Patterns of temperature adaptation in North American Atlantic coastal actinians. Mar Biol 7:123-130

Schutter M, Crocker J, Paijmans A, Janse M, Osinga R, Verreth AJ, Wijffels RH (2010) The effect of different flow regimes on the growth and metabolic rates of the scleractinian coral Galaxea fascicularis. Coral Reefs 29:737-748

Smith SV, Key GS (1975) Carbon dioxide and metabolism in marine environments. Limnol Oceanogr 20:493-495
Valencia V, Franco J, Borja Á, Fontán A (2004) Hydrography of the southeastern Bay of Biscay. Elsevier Oceanography Series 70:159-194

Van Oevelen D, Duineveld G, Lavaleye M, Mienis F, Soetaert K, Heip CHR (2009) The cold-water coral community as a hot spot for carbon cycling on continental margins: A food-web analysis from Rockall Bank (northeast Atlantic). Limnol Oceanogr 54:1829-1844

Walther GR, Post E, Convey P, Menzel A, Parmesan C, Beebee JC, Fromentin JM, Hoegh-Guldberg O, Bairlein F (2002) Ecological responses to recent climate change. Nature 416:389-395

Wild C, Huettel M, Klueter A, Kremb SG, Rasheed MYW, Jørgensen BB (2004) Coral mucus functions as an energy carrier and particle trap in the reef ecosystem. Nature 428:66-70

Wild C, Wehrmann LM, Mayr C, Schöttner SI, Allers E, Lundälv T (2009) Microbial degradation of cold-water coral-derived organic matter: potential implication for organic $\mathrm{C}$ cycling in the water column above Tisler Reef. Aquat Biol 7:71-80

Wild C, Mayr C, Wehrmann L, Schöttner S, Naumann M, Hoffmann F, Rapp HT (2008) Organic matter release by cold water corals and its implication for fauna-microbe interaction. Mar Ecol Prog Ser 372:67-75

Wildish D, Kristmanson D (1997) Benthic suspension feeders and flow. Cambridge University Press, Cambridge

Zibrowius H (1980) Les scléractiniaires de la Méditerranée et de l'Atlantique nord-oriental. Memoires de I'Institut océanographique, Monaco 11:1-284 